Article

\title{
Environmental Aspect of the Cement Manufacturing in the Świętokrzyskie Mountains (Southeastern Poland)
}

\author{
Rafał Kozłowski *(D, Mirosław Szwed (D) and Monika Żelezik
}

Citation: Kozłowski, R.; Szwed, M.; Żelezik, M. Environmental Aspect of the Cement Manufacturing in the Świętokrzyskie Mountains (Southeastern Poland). Minerals 2021, 11, 277. https://doi.org/10.3390/ $\min 11030277$

Academic Editor: Maria Economou-Eliopoulos

Received: 5 February 2021

Accepted: 5 March 2021

Published: 8 March 2021

Publisher's Note: MDPI stays neutral with regard to jurisdictional claims in published maps and institutional affiliations.

Copyright: (c) 2021 by the authors. Licensee MDPI, Basel, Switzerland. This article is an open access article distributed under the terms and conditions of the Creative Commons Attribution (CC BY) license (https:/ / creativecommons.org/licenses/by/ $4.0 /)$.
Institute of Geography and Environmental Sciences, Jan Kochanowski University, 25-406 Kielce, Poland; miroslaw.szwed@ujk.edu.pl (M.S.); monika.zelezik@ujk.edu.pl (M.Ż.)

* Correspondence: rafal.kozlowski@ujk.edu.pl; Tel.: +48-41-349-64-29

\begin{abstract}
The research area located in south-eastern Poland is exposed to alkaline pressure from a cement plant in Nowiny, which has been operating there since 1960. Both biotic and abiotic components of the natural environment remain in the zone of the plant's negative impact. Their reaction, described according to the concept of geo- and bioindicators, provides valuable information on the state of the natural environment in this area. In 2016-2018, the properties of precipitation were being investigated by determining its $\mathrm{pH}, \mathrm{EC}$ (specific electrolytic conductivity), and chemical composition in terms of the presence of selected heavy metals. Additionally, the chemical composition of samples of two-year-old pine needles, bark, and wood, as well as soil taken from the immediate vicinity of the cement plant, was analyzed. The analysis performed using the Inductively Coupled Plasma-Mass Spectrometer-Time-of-Flight (ICP-MS-TOF) showed the presence of heavy metals. The highest contents were recorded in soils $\left(\mathrm{Pb} 123 \mathrm{mg} \cdot \mathrm{kg}^{-1} ; \mathrm{Cr} 138 \mathrm{mg} \cdot \mathrm{kg}^{-1} ; \mathrm{Cu} 18 \mathrm{mg} \cdot \mathrm{kg}^{-1} ; \mathrm{Zn}\right.$ $\left.699 \mathrm{mg} \cdot \mathrm{kg}^{-1}\right)$, while the lowest ones were found in the wooden cores of drilled trees $\left(\mathrm{Pb} 0.1 \mathrm{mg} \cdot \mathrm{kg}^{-1}\right.$; Cr $1 \mathrm{mg} \cdot \mathrm{kg}^{-1}$; Cu $\left.0.1 \mathrm{mg} \cdot \mathrm{kg}^{-1} ; \mathrm{Zn} 4.1 \mathrm{mg} \cdot \mathrm{kg}^{-1}\right)$. On the basis of the research conducted on precipitation, it was found that the $\mathrm{pH}$ and $\mathrm{EC}$ values were increased, and the presence of heavy metals $(\mathrm{Pb}, \mathrm{Cr}, \mathrm{Ni}$, and $\mathrm{Cu})$ indicating a local source of pollution was indicated.
\end{abstract}

Keywords: heavy metals; mineral industry; air pollution

\section{Introduction}

Dyckerhoff Polska S.A. Cement Plant in Nowiny was established in 1960. Currently, it produces Portland cement using the dry method and ready-mixed concrete. The plant's production capacity is up to 500 tons of cement per $24 \mathrm{~h}$ and up to 260 tons of concrete per $24 \mathrm{~h}$. The plant's technological fuel is coal and mazout, and tires as alternative fuels. In 2016-2018, the average annual emission of dust to the atmosphere amounted to 36.2 tons, which is a value that is significantly lower than the values recorded, for example, in the 1980s when they were exceeding 24,000 tons per year [1]. The long-term operation of the cement plant caused significant changes in the natural environment [1-7]. The dust emitted to the atmosphere from the technological process of cement production contains potentially toxic heavy metals, strongly affecting the natural environment [8]. Chemical compounds present in cement dust also contain, apart from calcium, silica and iron oxides, heavy metals with a known degree of harmfulness to biological life [9,10]. The aim of this research is to determine the direction of heavy metal migration from cement dust to the natural environment by using selected geoindicators (precipitation, soil) and bioindicators (bark, needles, pine wood). Bioindication allows one to determine the reaction of a living organism to air pollution (including heavy metals contained in dust). The sensitivity to pollution and the potential for cumulation are used. Due to its common occurrence, we decided to use Scots pine as a bioindicator [11]. 


\section{Materials and Methods}

\subsection{Field Measurements}

The research was carried out using the evaluation system based on geoindications proposed by IUGS (International Union on Geological Sciences) [12,13] with regard to abiotic (precipitation and soil) and biotic components (pine needles, bark, and wood) [14-16]. Gases and solid particles in the air change the $\mathrm{pH}$ value, electrolytic conductivity, and chemical composition of precipitation [5]. The deposition of calcium-rich particles modifies the photosynthesis of coniferous trees [6,8] and causes soil alkalisation [17].

The research on precipitation was carried out in the area of Malik Mountain (267 m above sea level) at the Góra Malik Geoecological Station of the Jan Kochanowski University in Kielce, located in the southwestern part of the Świętokrzyskie Mountains. For this purpose, a Hellman rain gauge was used, mounted at a height of $27 \mathrm{~m}$, i.e., $1 \mathrm{~m}$ above the treetops. The research was conducted at weekly intervals in the years 2016-2018. The pH and EC (electrolytic conductivity) were tested each time in the field, using a Hach HQ 40d multiparameter water quality sensor equipped with an Intellical electrode.

Scots pine Pinus silvestris L. was selected for the bioindicating analyses due to its prevalence in the research area, forming dense complexes of upland and lowland forests with rich undergrowths and lower fir floors (Forest Data Bank). Two-year needles are considered to be the best for research, because the elder ones, especially those existing in a contaminated environment, may not be present anymore [18]. Two-year-old needles of Scots pine Pinus sylvestris L. were collected in October 2018 from the area in the immediate vicinity of the cement plant in an amount of approx. $200 \mathrm{~g}$ for each sampling point (Figure 1). The research sample consisted of mixed and averaged samples collected from about six trees of various ages, from a height of approx. $3 \mathrm{~m}$ a.s.1., at each designated sampling point. The diameter of each tree was about $45 \mathrm{~cm}$. The needles were taken from the whorl, on the top of tree, from the most exposed places possible. Bark, in turn, was taken in an amount of approx. $200 \mathrm{~g}$ from a height of approx. $3 \mathrm{~m}$. Wood samples were collected using a Pressler increment borer. The trees were being drilled from north to south, at the height of the breast. Soil samples were taken using an Egner's stick (mixed sample collected up to $20 \mathrm{~cm}$ deep) as the average of 10 soil punctures around the tree at a distance of approx. $2 \mathrm{~m}$ from its trunk. The background area was located (reference sample) at a distance of about $30 \mathrm{~km}$ northeast of the study area (in the Suchedniowsko-Oblegorski Landscape Park).

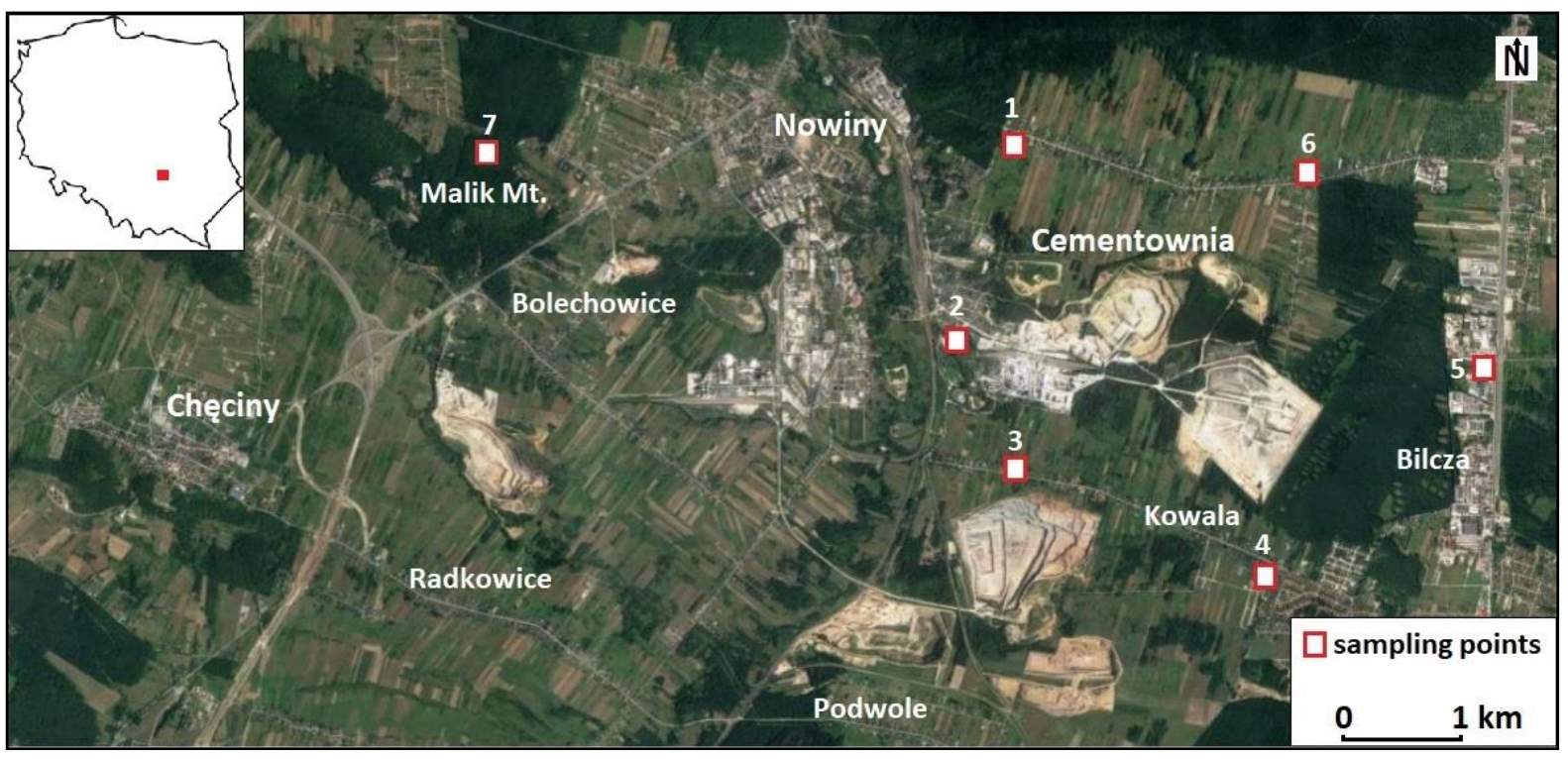

Figure 1. Research area location (based on Google Map). 


\subsection{Laboratory Analysis}

Samples collected in the field were transported to the Environmental Research Laboratory. Water was filtered using a GF/D Whatman glass filter into a polytetrafluoroethylene (PTFE) container. The collected samples were being stored in a thermostatic cabinet at a temperature of $+4{ }^{\circ} \mathrm{C}$. After a one-month sampling cycle, the samples were analyzed for their chemical composition as a collective sample, including precipitation waters from one month. Needle and bark samples were washed three times with deionized water. After having been dried at $65{ }^{\circ} \mathrm{C}$ for $24 \mathrm{~h}$, the air-dried samples (needles, bark, and wooden cores) were ground in an IKA A-11 Basic organic matter mill. Soil samples were ground in a ceramic mortar. A mixture of nitric acid (Suprapur Merck) and hydrogen peroxide in a ratio of 2.5:1 was used for distributing wet samples of 0.1-g weighed amounts in PTFE vessels. Material prepared in that way was subjected to microwave waves of $1400 \mathrm{~W}$ power and a temperature of $200{ }^{\circ} \mathrm{C}$ for 40 min using the Multiwave 3000 Anton Paar mineralizer. After mineralization, the samples were subjected to chemical analysis for the content of the selected metals $(\mathrm{Pb}, \mathrm{Cd}, \mathrm{Cr}, \mathrm{Co}, \mathrm{Cu}, \mathrm{Mn}, \mathrm{Ni}, \mathrm{Zn}, \mathrm{Sr}, \mathrm{Fe}$, and $\mathrm{Al})$ using the Inductively Coupled Plasma-Mass Spectrometer-Time-of-Flight (ICP-MS-TOF) OptiMass 9500 (GBC Scientific Equipment, Melbourne, Australia). The calibration curve was based on the CLMS 3AN standard. The following contents have been prepared for calibration: 0 (blank), 10, 50 , and $100 \mu \mathrm{g} \cdot \mathrm{dm}^{-3}$. To verify the correctness of the obtained results, a sample of the CRM was also analyzed (Table 1). The $\mathrm{pH}$ of the soil was potentiometrically measured in a supernatant suspension of 1:2.5 soil:liquid mixture using the Hach HQ 40d multiparameter; both deionized water and neutral salt $(1 \mathrm{M} \mathrm{KCl})$.

Table 1. The concentration of elements in the certified ERM-CA713 reference material.

\begin{tabular}{cccccc}
\hline \multirow{2}{*}{ Metals } & \multicolumn{2}{c}{ ERM CA713 } & \multicolumn{2}{c}{ ICP-MS-TOF } & \multirow{2}{*}{$\begin{array}{c}\text { Difference * } \\
\%\end{array}$} \\
\cline { 2 - 5 } & $\begin{array}{c}\text { Content } \\
\left(\mu \mathbf{g} \cdot \mathbf{d m}^{-3}\right)\end{array}$ & $\begin{array}{c}\text { Uncertainty } \\
\left(\mu \mathbf{\mu} \cdot \mathbf{d m}^{-3}\right)\end{array}$ & $\begin{array}{c}\text { Content } \\
\left(\mu \mathbf{g} \cdot \mathbf{d m}^{-3}\right)\end{array}$ & $\begin{array}{c}\text { Standard } \\
\text { Deviation }\end{array}$ & \\
\hline $\mathrm{Cd}$ & 5.09 & 0.3 & 4.99 & \pm 2.7 & -2.0 \\
\hline $\mathrm{Cr}$ & 20.9 & 0.2 & 19.7 & \pm 2.0 & -5.0 \\
\hline $\mathrm{Cu}$ & 101.0 & 1.3 & 99.4 & \pm 1.9 & -1.0 \\
\hline $\mathrm{Fe}$ & 445.0 & 27.0 & 430.0 & \pm 1.8 & -3.0 \\
\hline $\mathrm{Mn}$ & 95.0 & 4.0 & 97.8 & \pm 2.8 & 2.9 \\
\hline $\mathrm{Ni}$ & 50.3 & 1.4 & 53.0 & \pm 4.3 & 5.0 \\
\hline $\mathrm{Pb}$ & 49.7 & 1.7 & 51.8 & \pm 3.7 & 4.0 \\
\hline * Relative difference between the measured and certified concentrations $100 \% \cdot(\mathrm{cz}-\mathrm{cc}) / \mathrm{cc}$. &
\end{tabular}

\subsection{Statistical Analysis}

A statistical analysis was performed using Statistica 13.0 software. In order to determine the significance of differences among the analyzed variables, a nonparametric Mann-Whitney U test was used. In the next stage, a PCA (Principal Compound Analysis) and cluster analysis were also used. Chemical components were shown by pictorial chart.

\section{Results}

The analysis of the dust samples from the Dyckerhoff Polska S.A. Cement Plant in Nowiny showed a significant share of heavy metals in their composition. The largest share was represented by $\mathrm{Al}, \mathrm{Pb}, \mathrm{Zn}, \mathrm{Fe}, \mathrm{Cd}, \mathrm{Ni}, \mathrm{Cu}, \mathrm{Cr}$, and $\mathrm{Co}$. The $\mathrm{pH}$ of the samples was alkaline, and its value in $\mathrm{H}_{2} \mathrm{O}$ and $\mathrm{KCl}$ amounted to $\mathrm{pH}_{\mathrm{H} 20} 12.61$ and $\mathrm{pH}_{\mathrm{KCl}}$ 12.38. Based on the analysis of the conducted research results, it was found that, among the indicators used, the highest contents of heavy metals were recorded successively in soil, and then in bark, needles, and wood (Table 2). 
Table 2. Results of the chemical analyses of individual indicators.

\begin{tabular}{|c|c|c|c|c|c|c|c|c|c|c|c|c|}
\hline \multirow{2}{*}{ Indicator } & \multirow{2}{*}{ Feature } & $\mathrm{Pb}$ & $\mathrm{Cd}$ & $\mathrm{Cr}$ & Co & $\mathrm{Cu}$ & Mn & $\mathrm{Ni}$ & Zn & Al. & $\mathrm{Fe}$ & $\mathrm{pH}$ \\
\hline & & \multicolumn{10}{|c|}{$\mathrm{mg} \cdot \mathrm{kg}^{-1}$ d.m. } & {$[-]$} \\
\hline \multirow{6}{*}{ 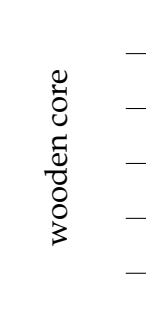 } & Min & $<0.096$ & $<0.056$ & 1.01 & $<0.031$ & 0.02 & 3.34 & 0.45 & 4.05 & 0.18 & $<0.024$ & 4.00 \\
\hline & Max & 0.13 & 2.58 & 3.80 & 0.62 & 4.09 & 14.0 & 4.88 & 6.02 & 9.48 & 127.6 & 4.83 \\
\hline & Avg & 0.10 & 1.64 & 2.26 & 0.30 & 2.25 & 7.23 & 2.41 & 5.25 & 4.33 & 57.0 & 4.45 \\
\hline & SD & 0.02 & 1.02 & 1.11 & 0.23 & 1.36 & 4.25 & 1.64 & 0.77 & 3.05 & 56.5 & 0.27 \\
\hline & $\mathrm{CV}$ & 16.0 & 61.1 & 49.3 & 72.6 & 60.4 & 58.9 & 68.1 & 14.8 & 70.3 & 99.0 & 6.27 \\
\hline & reference sample & $<0.096$ & 0.20 & 0.38 & $<0.031$ & 0.70 & 3.83 & $<0.018$ & 1.60 & 4.17 & 10.2 & 3.57 \\
\hline \multirow{6}{*}{$\frac{\mathscr{\mathscr { q }}}{\frac{\mathscr{Z}}{\mathscr{\Xi}}}$} & Min & $<0.096$ & $<0.056$ & $<0.116$ & $<0.031$ & 0.18 & 9.98 & $<0.018$ & 20.7 & 88.9 & 24.1 & 4.64 \\
\hline & Max & 1.40 & 2.94 & 2.68 & 0.32 & 3.72 & 143.0 & 5.64 & 32.4 & 211.1 & 68.7 & 6.01 \\
\hline & Avg & 0.50 & 1.15 & 0.78 & 0.14 & 1.51 & 50.3 & 2.26 & 26.2 & 118.6 & 44.1 & 5.15 \\
\hline & SD & 0.63 & 1.36 & 0.95 & 0.12 & 1.51 & 48.0 & 2.53 & 4.74 & 45.8 & 16.3 & 0.55 \\
\hline & $\mathrm{CV}$ & 126.3 & 118.5 & 122.7 & 90.2 & 100.1 & 95.2 & 112.2 & 18.1 & 38.6 & 36.9 & 10.7 \\
\hline & reference sample & 0.17 & 0.39 & 1.56 & $<0.031$ & 1.36 & 585.9 & 1.49 & 15.5 & 57.4 & 18.1 & 4.53 \\
\hline \multirow{6}{*}{ 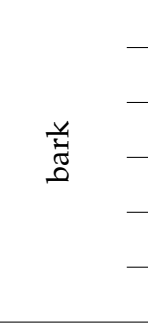 } & Min & 0.82 & $<0.056$ & $<0.116$ & $<0.031$ & 0.42 & 6.55 & $<0.018$ & 11.7 & 102.5 & 51.0 & 4.91 \\
\hline & Max & 17.3 & 2.01 & 2.83 & 1.10 & 8.26 & 25.70 & 4.40 & 26.4 & 756.6 & 345.2 & 6.50 \\
\hline & Avg & 8.32 & 1.20 & 0.77 & 0.35 & 3.98 & 14.70 & 2.20 & 16.8 & 387.1 & 175.4 & 5.48 \\
\hline & SD & 5.70 & 0.82 & 1.12 & 0.41 & 2.88 & 8.88 & 2.06 & 6.21 & 283.3 & 126.7 & 0.57 \\
\hline & $\mathrm{CV}$ & 68.6 & 68.1 & 145.1 & 119.3 & 72.3 & 60.4 & 93.9 & 37.0 & 73.2 & 72.2 & 10.5 \\
\hline & reference sample & 7.25 & 1.04 & 0.61 & 0.00 & 3.83 & 35.6 & 1.98 & 12.44 & 378.0 & 250.2 & 4.47 \\
\hline \multirow{6}{*}{$\bar{\varnothing}$} & Min & 12.4 & $<0.056$ & 46.4 & $<0.031$ & 0.45 & 76.0 & $<0.018$ & 24.0 & 1523 & 1257 & 7.20 \\
\hline & Max & 123.3 & $<0.056$ & 138.0 & 6.54 & 17.9 & 504.6 & 27.5 & 699.4 & 29,334 & 10,545 & 8.44 \\
\hline & Avg & 47.7 & $<0.056$ & 88.9 & 1.76 & 8.27 & 194.9 & 5.90 & 195.0 & 8520 & 3885 & 7.53 \\
\hline & SD & 43.2 & & 30.3 & 2.42 & 6.27 & 154.9 & 11.0 & 263.6 & 10,523 & 3470 & 0.46 \\
\hline & $\mathrm{CV}$ & 90.5 & & 34.0 & 137.5 & 75.8 & 79.49 & 187.2 & 135.2 & 123.5 & 89.3 & 6.17 \\
\hline & reference sample & 8.28 & 0.53 & 20.4 & 1.64 & 7.72 & 1583 & 4.43 & 61.6 & 60,463 & 9245 & 5.11 \\
\hline
\end{tabular}

$<$ under LOQ. SD: standard deviation; CV: coefficient of variation.

The sequence of the analyzed metals was being shaped in a highest-lowest order in individual indicators:

$\begin{array}{cl}\text { Soil } & \mathrm{Al}>\mathrm{Fe}>\mathrm{Zn}>\mathrm{Mn}>\mathrm{Cr}>\mathrm{Pb}>\mathrm{Sr}>\mathrm{Cu}>\mathrm{Ni}>\mathrm{Co}>\mathrm{Cd} \\ \text { Bark } & \mathrm{Al}>\mathrm{Fe}>\mathrm{Zn}>\mathrm{Mn}>\mathrm{Pb}>\mathrm{Sr}>\mathrm{Cu}>\mathrm{Ni}>\mathrm{Cd}>\mathrm{Cr}>\mathrm{Co} \\ \text { Needles } & \mathrm{Al}>\mathrm{Mn}>\mathrm{Fe}>\mathrm{Zn}>\mathrm{Sr}>\mathrm{Ni}>\mathrm{Cu}>\mathrm{Cd}>\mathrm{Cr}>\mathrm{Pb}>\mathrm{Co} \\ \text { Wood } & \mathrm{Fe}>\mathrm{Mn}>\mathrm{Zn}>\mathrm{Al}>\mathrm{Ni}>\mathrm{Cr}>\mathrm{Cu}>\mathrm{Cd}>\mathrm{Sr}>\mathrm{Co}>\mathrm{Pb}\end{array}$

In the case of soil samples, the highest contents (with an average amounting to over 8500 and $3800 \mathrm{mg} \cdot \mathrm{kg}^{-1}$, respectively) were recorded for $\mathrm{Al}$ and Fe. The next metal, which was decreasing in the sequence, was zinc, whose content in soil reached $700 \mathrm{mg} \cdot \mathrm{kg}^{-1}$ (with an average of $195 \mathrm{mg} \cdot \mathrm{kg}^{-1}$ ). It was followed by manganese (about $500 \mathrm{mg} \cdot \mathrm{kg}^{-1}$, with an average of $194.9 \mathrm{mg} \cdot \mathrm{kg}^{-1}$ ), chromium (approx. $140 \mathrm{mg} \cdot \mathrm{kg}^{-1}$, with an average of $\left.88.8 \mathrm{mg} \cdot \mathrm{kg}^{-1}\right)$, and lead $\left(120 \mathrm{mg} \cdot \mathrm{kg}^{-1}\right.$, with an average of $\left.47.7 \mathrm{mg} \cdot \mathrm{kg}^{-1}\right)$. The content of other metals did not exceed $100 \mathrm{mg} \cdot \mathrm{kg}^{-1}$ (Table 2).

Needle, bark, and wood samples were characterized by contents of metals (i.e., $\mathrm{Cd}$, $\mathrm{Cr}, \mathrm{Co}, \mathrm{Cu}$, and $\mathrm{Ni}$ ) that were comparable to each other (all below $5 \mathrm{mg} \cdot \mathrm{kg}^{-1}$ ). However, they were lower than those recorded in the soil samples. Significant amounts of lead were found in the bark samples (with an average of $8.3 \mathrm{mg} \cdot \mathrm{kg}^{-1}$ ). They were higher than in the needle samples (average of $0.5 \mathrm{mg} \cdot \mathrm{kg}^{-1}$ ) or the wooden core samples, where no $\mathrm{Pb}$ was 
recorded (Figure 2). It was found that the contents of heavy metals in the analyzed samples collected around the cement plant were higher in most cases (except for $\mathrm{Al}$ and $\mathrm{Fe}$ ) than in those collected from the reference plot located $40 \mathrm{~km} \cdot \mathrm{NW}$ from the research area.

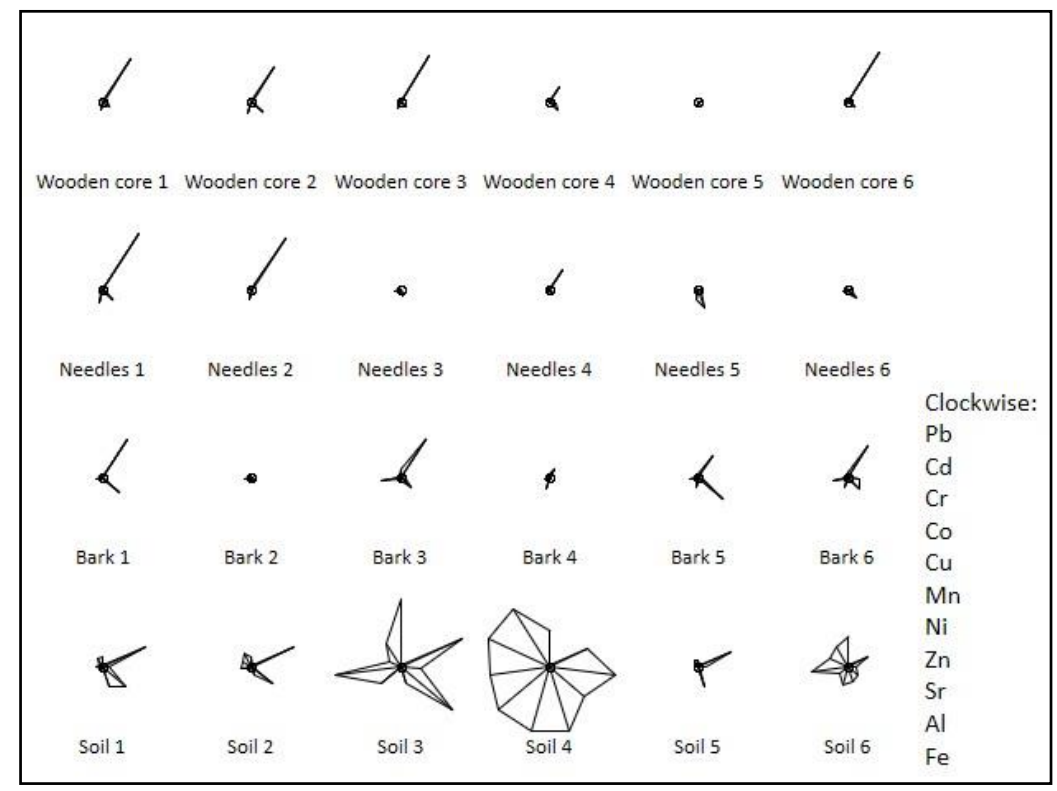

Figure 2. Pictorial chart of the heavy metal contents in indicators.

The analysis conducted using the nonparametric Mann-Whitney U test showed statistically significant equations between the results obtained in the samples of individual indicators. In the case of soil samples, the contents of $\mathrm{Pb}, \mathrm{Cr}, \mathrm{Mn}, \mathrm{Zn}, \mathrm{Fe}$, and $\mathrm{Al}$ differed significantly from the results obtained in the bark, needle, and wood samples; in the case of $\mathrm{Cd}$, in the bark and wood samples; in the case of $\mathrm{Sr}$, in the needle and wood samples; and in the case of $\mathrm{Co}$ and $\mathrm{Cu}$, only in the needle samples.

Thanks to the cluster analysis, measuring surfaces were grouped (Figure 3). Surfaces 6,4 , and 2 , showing similar features, constituted group I. It consisted of sites east of the cement plant and in its immediate vicinity. The highest contents of metals were recorded, which in the case of surfaces no. 6 and 4 were influenced by the winds from the west, dominating in this area, which caused the dispersion of pollutants. The second group consisted of surfaces no. 3, 1, and 5. The first two were located to the west of the cement plant. The average contents of metals were recorded there. In this group, the surface no. 5 could be distinguished, located to the east of the cement plant, where the contents of $\mathrm{Pb}, \mathrm{Cd}, \mathrm{Cr}, \mathrm{Co}, \mathrm{Ni}, \mathrm{Cu}, \mathrm{Zn}$, and $\mathrm{Sr}$ were the lowest. The observed spatial variability of the contents of the selected metals indicates that dense forest complexes significantly reduce the spread of pollutants.

The weighted average $\mathrm{pH}$ value of precipitation in the analyzed period was 6.19. In 2016, the weighted average $\mathrm{pH}$ value of precipitation was 5.91 (normal precipitation according to the classification by Jansen et al. [19]), with fluctuations from 5.30 (January 2016) to 6.57 (May 2016). The electrolytic conductivity (EC) was $4.50 \mathrm{mS} \cdot \mathrm{m}^{-1}$ (significantly elevated). In 2017, the average $\mathrm{pH}$ value was 6.47 (slightly elevated) and the conductivity was $7.12 \mathrm{mS} \cdot \mathrm{m}^{-1}$ (extremely elevated). The lowest $\mathrm{pH}$ for precipitation was recorded in winter. In 2018, a slightly elevated $\mathrm{pH}$ (6.15) and extremely elevated electrolytic conductivity $\left(9.95 \mathrm{mS} \cdot \mathrm{m}^{-1}\right)$ were found. For individual months during the analyzed period, the phenomenon of the lowest $\mathrm{pH}$ values recorded in the winter months is repeated, which results from increased contents of dust and gases produced by municipal heating sectors (low emissions). The analysis of the content of selected heavy metals showed the highest contents of iron, copper, aluminum, and nickel in the atmospheric precipitation taking place during the research period. The contents of other heavy metals did not exceed 
$100 \mu \mathrm{g} \cdot \mathrm{dm}^{-3}$ in the average monthly precipitation samples. The highest contents of iron in the monthly sample was found in winter, in January $2016\left(580 \mu \mathrm{g} \cdot \mathrm{dm}^{-3}\right)$. The highest contents for copper $\left(180 \mu \mathrm{g} \cdot \mathrm{dm}^{-3}\right)$ and aluminum $\left(57.5 \mu \mathrm{g} \cdot \mathrm{dm}^{-3}\right)$ were found, in turn, in September 2018.

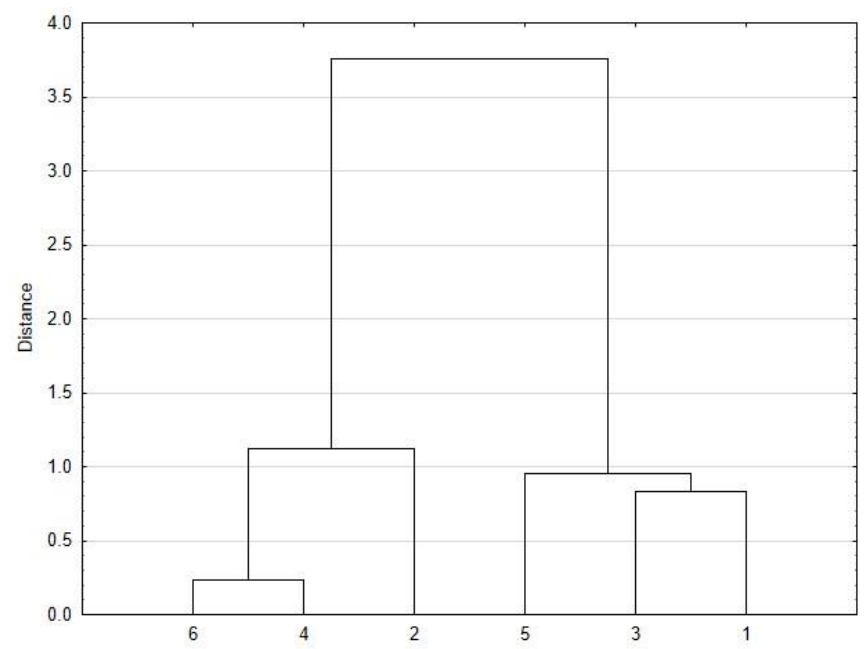

Figure 3. Cluster analysis results (Ward's method, Manhattan distance).

Using the principal component analysis in the case of precipitation, three main components PC1-PC3 were distinguished (Table 3). In total, they generated $81 \%$ of the variability in the given samples. They take into account the conditions resulting from both the cement and lime industry operating in this area (components PC1-PC2), as well as the municipal and living sector (component PC3).

Table 3. PCA analysis results.

\begin{tabular}{cccc}
\hline Features & PC1 & PC2 & PC3 \\
\hline $\mathrm{pH}$ & 0.234 & -0.360 & $-0.7322^{*}$ \\
$\mathrm{EC}$ & -0.526 & -0.479 & -0.238 \\
$\mathrm{~Pb}$ & $-0.701^{*}$ & -0.175 & 0.418 \\
$\mathrm{Cd}$ & -0.637 & -0.541 & 0.297 \\
$\mathrm{Cr}$ & -0.445 & 0.650 & 0.082 \\
$\mathrm{Co}$ & $-0.804^{*}$ & 0.479 & -0.075 \\
$\mathrm{Cu}$ & $-0.827^{*}$ & -0.457 & 0.032 \\
$\mathrm{Mn}$ & $-0.768^{*}$ & 0.533 & -0.211 \\
$\mathrm{Ni}$ & -0.599 & $0.759 *$ & -0.172 \\
$\mathrm{Sr}$ & -0.586 & -0.525 & -0.432 \\
$\mathrm{Al}$ & $-0.837^{*}$ & -0.432 & 0.232 \\
$\mathrm{Fe}$ & $-0.936^{*}$ & 0.145 & -0.222 \\
\% variance & 47 & 24 & 10 \\
Total \% & 47 & 71 & 81 \\
\hline
\end{tabular}

${ }^{*} \mathrm{PC} 1$ and $\mathrm{PC} 3 \leq-0.7 ; \mathrm{PC} 2 \geq 0.65$.

The components (PC1 and PC2) representing the influence of the cement and lime industry generated $71 \%$ of the total variance. The PC1 component showed a high weight $(\leq-0.7)$ for $\mathrm{Pb}, \mathrm{Co}, \mathrm{Cu}, \mathrm{Mn}, \mathrm{Al}$, and $\mathrm{Fe}$ (Table 2). The second component (PC2 $\geq 0.7)$, in turn, accounted for $24 \%$ of the total variance, with the highest weight for $\mathrm{Ni}$ (Figure 4 ). The PC3 component (10\% of the total variance) was also important, indicating a high weight for the $\mathrm{pH}(-0.7)$. 

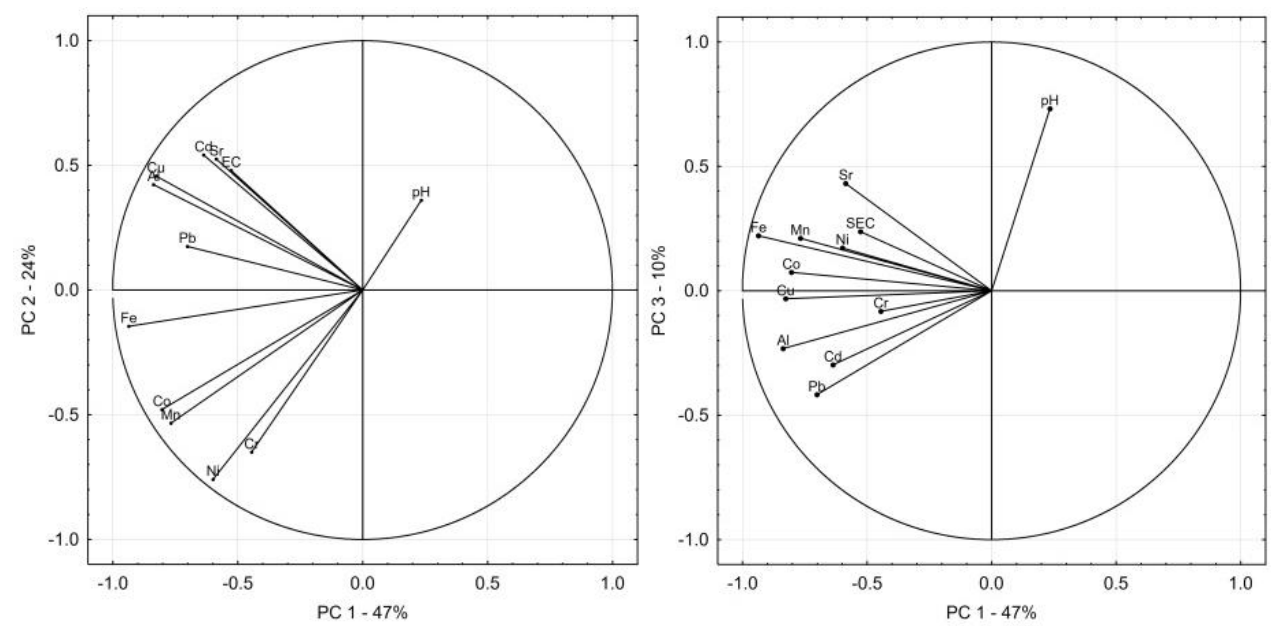

Figure 4. Graphical representation of the relationship among PC1, PC2, and PC3 components.

\section{Discussion}

The presence of heavy metals in the soil around the cement plant is a potential threat to the natural environment. Only the contents of aluminum and iron are a natural consequence of rock and mineral weathering, and are not treated as anthropogenic pollution in the research area [20]. The content of heavy metals in soils varies widely [10,21]. Metals getting into soil may undergo various transformations, ranging from deposition in the form of insoluble compounds with a relatively low impact on plants and micro-organisms, to occurrence in a very active ionized form. They may also form chelate connections with humic substances, which provide protection against the toxic effects of a metal ion. Calcium and aluminum are significant elements stabilizing the organic and mineral structure of soil. The presence of heavy metals in soil favors the destruction of this structure-heavy metals compete with the organic substance for adsorption space on the mineral surface. In the presence of metals, the precipitation of humic-metallic compounds may also occur [22] The binding of individual metals by the organic substance is different and depends not only on soil $\mathrm{pH}$ but also on the type of metal [23,24].

The physical and chemical properties of precipitation from this region are characterized by increased $\mathrm{pH}$ and EC values, which is typical for areas with cement and lime pressure. Similar values were recorded for the atmospheric precipitation under the pine canopy in the Górażdże forest complex near the city of Opole, exposed to emissions from cement and lime plants [25]. Similarly, high values of precipitation $\mathrm{pH}$ in the range of 4.6-6.9 (with an average $\mathrm{pH}$ of 5.48) and EC in the range of 1.1-30.6 mS. $\mathrm{m}^{-1}$ (with an average of $7.2 \mathrm{mS} \cdot \mathrm{m}^{-1}$ ) were recorded in the ecosystem of a degraded forest on limestone rocks of the Yunan Province (China) [26]. The results of the chemical composition of precipitation on the Malik Mountain were similar to the contents of nickel, cadmium, cobalt, and chromium obtained on the basis of atmospheric precipitation in the region of Upper Silesia in Poland [27]. In all the years of research, the average annual contents of iron and copper in the precipitation water from this region were several times higher than those obtained in the Upper Silesian urban area. Research on precipitation waters, conducted recently in other regions of the world, especially in sparsely populated areas and those with no industrial sites, does not show increased contents of heavy metals [28-35].

The observed diversified metal contents showed that the use of one indicator (soil, pine needles, pine bark, drill holes, precipitation) did not fully explain the changes taking place in areas under significant pressure. Moreover, the use of only single indicators may lead to the formulation of overly far-reaching conclusions.

The conducted research confirmed the effectiveness of the indicators that were used in order to assess the directions of pollution migration in an area with long-term anthropogenic pressure, as noted by Degórski [36] and de Alba et al. [37] in other regions of Europe. The migration of metals to bioindicators from the air is confirmed by the research 
conducted by other scientists. The high level of heavy metals found in the soils and much lower one recorded for the tree trunks may result from the strong alkalization of soils in this area. As Parzych et al. [38] note, it is an increase in soil acidity that affects the bioavailability of selected heavy metals ( $\mathrm{Mn}, \mathrm{Fe}$ ) in pine needles. Cement and lime dust, consisting mainly of calcium oxide, modify the soil environment most strongly. Excess calcium carbonate reduces the absorption of many metals, including iron, aluminum, zinc, copper, and manganese, and also accelerates the development of soil humus. The research conducted by Kozłowski [1] showed that the contents of calcium in rusty podzolic soils at the Góra Malik Geoecological Station, for the samples collected from the vicinity of beech trunks, ranged from $2882 \mathrm{mg} \cdot \mathrm{kg}^{-1}$ at a distance of $10 \mathrm{~cm}$ to $7685 \mathrm{mg} \cdot \mathrm{kg}^{-1}$ at a distance of $300 \mathrm{~cm}$ from the beech tree trunks.

Research in other regions of the world, including that conducted in the impact zone of the largest copper and nickel smelter in Russia, showed similar levels of metal accumulation in pine biomass [39]. In turn, the research by Butkus et al. [40] on former military training grounds highly contaminated with heavy metals in soils did not show any phytotoxic exceedances within the tree cores of the analyzed trees.

\section{Conclusions}

As a result of local emissions, the chemical composition of atmospheric precipitation in this region shows the influence of dust pollution from a nearby cement plant. The observed values of the contents of metals analyzed in precipitation are characterized by a large variation throughout a year. The share of heavy metals in individual bioindicators does not confirm a significant role of element migration. As a result of the soil environment alkalization, the metals trapped in the chelate complexes are not accessible to the roots of the analyzed trees.

When identifying changes caused by high-frequency factors (air quality), the best diagnostic properties were shown successively: atmospheric precipitation $(\mathrm{pH})$ as well as pine needles and bark (accumulation of heavy metals). On the other hand, the soil samples showed the best properties for determining low-frequency changes. To sum up, the conducted research confirmed the effectiveness of the indicators that were used.

Author Contributions: Conceptualization, R.K., M.S., and M.Ż.; methodology, R.K., M.S., and M.Ż.; software, R.K., M.S.; validation, R.K.; formal analysis, M.S. and R.K.; investigation, M.S. and R.K.; resources, M.S.; data curation, R.K., M.S., and M.Ż.; writing—original draft preparation, M.S.; writing-review and editing, R.K. and M.S.; visualization, R.K. and M.S.; supervision, R.K., M.S., and M.Ż.; project administration, R.K., M.S., and M.Ż.; funding acquisition, R.K., M.S., and R.K. All authors have read and agreed to the published version of the manuscript.

Funding: This research was funded by The Jan Kochanowski University in Kielce, grants number 638 and 648 .

Data Availability Statement: Not applicable.

Conflicts of Interest: The authors declare no conflict of interest.

\section{References}

1. Kozłowski, R. The functioning of selected Polish geoecosystems under diverse anthropopressure conditions: The case of low mountains and foothills. Landf. Anal. 2013, 23, 1-150.

2. Jóźwiak, M.A.; Jóźwiak, M. Influence of cement industry on accumulation of heavy metals in bioindicators. Ecol. Chem. Eng. 2009, 16, 323-334.

3. Barga-Więcławska, A.J.; Świercz, A. A long-term influence of anthropogenic alkalization on molluscs biodiversity in an area affected by cement industry, Świętokrzyskie Mountains, South-Central Poland. Arch. Environ. Prot. 2015, 41, 49-61. [CrossRef]

4. Kozłowski, R.; Jóźwiak, M. Transformacja opadów atmosferycznych w strefie drzew wybranych ekosystemów leśnych w Górach Świętokrzyskich. Przegląd Geogr. 2017, 89, 133-153. [CrossRef]

5. Kozłowski, R.; Kruszyk, R.; Małek, S. The Effect of Environmental Conditions on Pollution Deposition and Canopy Leaching in Two Pine Stands (West Pomerania and Świętokrzyskie Mountains, Poland). Forests 2020, 11, 535. [CrossRef]

6. Szwed, M.; Kozłowski, R.; Żukowski, W. Assessment of Air Quality in the South-Western Part of the Świętokrzyskie Mountains Based on Selected Indicators. Forests 2020, 11, 499. [CrossRef] 
7. Ciupa, T.; Suligowski, R.; Biernat, T. Ingerencja człowieka w środowisko wodne Chẹcińsko-Kieleckiego Parku Krajobrazowego. Pradnik. Pr. i Mater. Muz. im. Prof. Wt. Szafera 2010, 20, 151-164.

8. Szwed, M.; Żukowski, W.; Kozłowski, R. The Presence of Selected Elements in the Microscopic Image of Pine Needles as an Effect of Cement and Lime Pressure within the Region of Białe Zagłębie (Central Europe). Toxics 2021, 9, 15. [CrossRef]

9. Gruca-Królikowska, S.; Wacławek, W. Metale w środowisku. Cz. II. Wpływ metali ciężkich na rośliny. Chem. Didact. Ecol. Metrol. 2006, 11, 41-56.

10. Kabata-Pendias, A.; Pendias, H. Biogeochemistry of Trace Elements; Polish Scientific Publisher: Warsaw, Poland, 2002.

11. Dmuchowski, W.; Bytnerowicz, A. Monitoring environmental pollution in Poland by chemical analysis of Scots pine (Pinus sylvestris L.) needles. Environ. Pollut. 1995, 87, 87-104. [CrossRef]

12. Berger, A.; Iams, W. Geoindicators: Assessing Rapid Environmental Changes in Earth Systems; A.A. Balkema: Rotterdam, The Netherlands; Brookfield, VT, USA, 1996; p. xi + 466, ISBN 90-5410-631-X.

13. Kozłowski, R.; Jóźwiak, M. The use of selected geoindicators to assess the functioning of the geoecosystem in the central part of the Holy Cross Mountains. Monit. Nat. Environ. 2015, 17, 21-26.

14. Grodzinski, W.; Yorks, T.P. Species and ecosystem level bioindicators of airborne pollution: An analysis of two major studies. Water Air Soil Pollut. 1981, 16, 33-53. [CrossRef]

15. Świercz, A. Rola biowskaźników w monitoringu zanieczyszczeń środowiska i rekultywacji terenów poprzemysłowych. Probl. Ekol. Kraj. PAEK 2004, 1, 235-241.

16. Asif, N.; Nazir, F.; Malik, M. A Review of on Environmental Pollution Bioindicators. Pollution 2018, 4, 111-118.

17. Świercz, A.; Gandzel, A.; Tomczyk-Wydrych, I. Dynamics of Changes in Selected Soil Traits in the Profiles of Arable Soils Anthropogenically Alkalised by the Cement and Lime Industry within the Kielecko-Łagowski Vale (Poland). Land 2021, 10, 84. [CrossRef]

18. Chudzińska, E.; Celiński, K.; Pawlaczyk, E.M.; Wojnicka-Półtorak, A.; Diatta, J.B. Trace element contamination differentiates the natural population of Scots pine: Evidence from DNA microsatellites and needle morphology. Environ. Sci. Pollut. Res. 2016, 23, 22151-22162. [CrossRef]

19. Jansen, W.; Block, A.; Knaack, J. Acid rain. History, generation, results. Aura 1988, 4, 18-19.

20. Gałuszka, A.; Migaszewski, Z. Geochemical background-an environmental perspective. Mineralogia 2011, 42, 7-17. [CrossRef]

21. Dziadek, K.; Wacławek, W. Metale w środowisku. Cz. I. Metale ciężkie (Zn, Cu, Ni, Pb, Cd) w środowisku glebowym. Chem. Didact. Ecol. Metrol. 2005, 10, 33-44.

22. Badora, A. Wpływ pH na mobilność pierwiastków w glebach. Zesz. Probl. Post. Nauk. Roln. 2002, 482, 21-36.

23. Adriano, D.C. Trace Elements in the Terrestrial Environment; Springer: New York, NY, USA; Heidelberg, Germany, 1986.

24. Alloway, R.J. Heavy Metals in Soils; Backie Glasgow: London, UK; John Wiley \& Sons: New York, USA, 1990.

25. Sporek, M. Effect of the cement and limestone industry on the chemical properties of water beneath tree canopies. Ecol. Chem. Eng. A 2018, 25, 207-214.

26. Lu, P.; Han, G.; Wu, Q. Chemical characteristics of rainwater in karst rural areas, Guizhou Province, Southwest China. Acta Geochim. 2017, 36, 572-576. [CrossRef]

27. Kosior, G.; Samecka-Cymerman, A.; Brudzinska-Kosior, A. Transplanted moss Hylocomium splendens as a bioaccumulator of trace elements from different categories of sampling sites in the Upper Silesia area (SW Poland): Bulk and dry deposition impact. Bull. Environ. Contam. Toxicol. 2018, 101, 479-485. [CrossRef] [PubMed]

28. Hu, G.P.; Balasubramanian, R. Wet deposition of trace metals in Singapore. Water Air Soil Pollut. 2003, 144, 285-300. [CrossRef]

29. Conko, K.M.; Rice, K.C.; Kennedy, M.M. Atmospheric wet deposition of trace elements to a suburban environment, Reston, Virginia, USA. Atmos. Environ. 2004, 38, 4025-4033. [CrossRef]

30. Zhang, Q.; Kang, S.; Cong, Z.; Hou, S.; Liu, Y. Elemental composition in surface snow from the ultra-high elevation area of Mt. Qomolangma (Everest). China Sci. Bull. 2008, 53, 289-294. [CrossRef]

31. Aizen, V.B.; Mayewski, P.A.; Aizen, E.M.; Joswiak, D.R.; Surazakov, A.B.; Kaspari, S.; Grigholm, B.; Krachler, M.; Handley, M.; Finaev, A. Stable-isotope and trace element time series from Fedchenko glacier (Pamirs) snow/firn cores. J. Glaciol. 2009, 55, 275-291. [CrossRef]

32. Koulousaris, M.; Aloupi, M.; Angelidis, M.O. Total metal concentrations in atmospheric precipitation from the northern Aegean Sea. Water Air Soil Pollut. 2009, 201, 389-403. [CrossRef]

33. Ozsoy, T.; Ornektekin, S. Trace elements in urban and suburban rainfall, Mersin, Northeastern Mediterranean. Atmos. Res. 2009, 94, 203-219. [CrossRef]

34. Sakata, M.; Asakura, K. Factors contributing to seasonal variations in wet deposition fluxes of trace elements at sites along Japan Sea coast. Atmos. Environ. 2009, 43, 3867-3875. [CrossRef]

35. Cong, Z.; Kang, S.; Zhang, Y.; Li, X. Atmospheric wet deposition of trace elements to central Tibetan Plateau. Appl. Geochem. 2010, 25, 1415-1421. [CrossRef]

36. Degórski, M. Wskaźnikowa rola gleby w ocenie przemian i jakości środowiska geograficznego na poziomie badań krajobrazowych—Przegląd koncepcji. In Idee i Praktyczny Uniwersalizm Geografii; Gierszewski, P., Karasiewicz, M.T., Eds.; Geografia Fizyczna, Dok Geog: Warsaw, Poland, 2006; Volume 32, pp. 55-56.

37. De Alba, S.; Lindstrom, M.; Schumacher, T.; Malo, D. Soil landscape evolution due to soil redistribution by tillage: A new conceptual model of soil catena evolution in agriculture landscapes. Catena 2004, 58, 77-100. [CrossRef] 
38. Parzych, A.; Mochnacký, S.; Sobisz, Z.; Kurhaluk, N.; Polláková, N. Accumulation of heavy metals in needles and bark of Pinus species. Folia For. Pol. 2017, 59, 34-44. [CrossRef]

39. Shcherbenko, T.A.; Koptsik, G.N.; Groenenberg, B.J.; Lukina, N.Y.; Livantsova, S.Y. Uptake of nutrients and heavy metals by pine trees under atmospheric pollution. Mosc. Univ. Soil. Sci. Bull. 2008, 63, 51-59. [CrossRef]

40. Butkus, D. Transport of heavy metals from soil to Pinus sylvestris L. and Betula pendula trees. Ekologija 2007, 53, 29-36. 